LAERE

MIDDEL

ODK

\title{
Læremidler i brug i danskfagets litteratur- undervisning
}

- en empirisk undersøgelse af litteraturanalyse og litteraturfortolkning i udskolingen

Af Maiken Sissel Norup

Korrekt citering af denne artikel efter APA-systemet (American Psychological Association System, 7th Edition): Norup, M. S. (2021). Læremidler i brug i danskfagets litteraturundervisning - en empirisk undersøgelse af litteraturanalyse og litteraturfortolkning i udskolingen. Learning Tech - Tidsskrift for læremidler, didaktik og teknologi, (2), 40-70. DOI: 10.7146/It.v6i9.124193 
Denne artikel præsenterer resultaterne fra et femugers casestudie af læremidler i brug i danskfagets litteraturundervisning i to 8. klasser. Fokus er på tre empiriske nedslag: 1) to læreres didaktiske designs, 2) videoobservation af litteraturundervisningen og 3) elevprodukter i form af padlets. Artiklens bidrag er dobbelt. Dels bidrager den med viden om, hvor stor en procentvis andel af de didaktiske designs, undervisningen og elevprodukterne, der udgør henholdsvis litteraturanalyse og -fortolkning. Dels bidrager den med viden om, hvordan litteraturanalyse og -fortolkning praktiseres i litteraturundervisningen. I undersøgelsen blev der udviklet et litteraturdidaktisk kodningssystem til analyse af det empiriske materiale med udgangspunkt i Benjamin Blooms taksonomi. Resultaterne viser, at analyse blev prioriteret højere end fortolkning. Fælles for både litteraturanalyse og -fortolkning var, at de begge blev praktiseret i et vakuum - isoleret fra hinanden og fra de resterende taksonomiske niveauer.

This article presents the results from a five-week case study of learning materials in use in literature teaching in Danish (L1) in two 8th grades. The focus is on three empirical perspectives: 1 ) two teachers' didactic designs, 2) video observation of the literature teaching and 3) student products in the form of padlets. The article's contribution is twofold. First, it contributes with knowledge on what percentages of both literature analysis and interpretation, respectively, is comprised by didactic designs, teaching and student products. Second, it contributes with knowledge on how literature analysis and interpretation is practiced in literature teaching. In the study, a literature didactic coding system was developed to analyze the empirical material based on Benjamin Bloom's taxonomy. The results show that analysis was given higher priority than interpretation. Both literature analysis and interpretation were practiced in a vacuum isolated from each other and from the remaining taxonomic levels. 


\section{Læremidler i brug i danskfagets litteratur- undervisning}

\section{- en empirisk undersøgelse af litteraturanalyse og litteraturfortolkning i udskolingen}

\section{Indledning}

I denne artikel præsenterer jeg et uddrag af en empirisk undersøgelse foretaget i forbindelse med mit kandidatspeciale (Norup, 2019). Formålet med undersøgelsen var at undersøge relationerne mellem to læreres didaktiske design og den faktiske anvendelse i undervisningen. Internationalt og nationalt er læremidler en stor del af skolens virkelighed på tværs af fag og niveauer (se fx Sikorová, 2011; Mullis, Martin, Foy \& Arora, 2012; Gilje, 2015). Forskning viser, at læremidlerne har stor indflydelse på lærernes planlægning af undervisning (Warren, 2000; Hodgson, Rønning, Skogvold \& Tomlinson, 2010; Stara \& Krčmářová, 2015; Bremholm \& Skott, 2019) og gennemførelse af undervisning (Sikorová, 2011; Schmidt, McKnight, Houang, Wang, Wiley, Cogan \& Wolfe, 2001). Dog varierer læremidlernes tilstedeværelse i klasserummet og påvirkning af undervisningen alt efter hvilket fag, der står til genstand for undersøgelse (se fx Sigurgeirsson, 1992; HeyerdahlLarsen, 2000). Det er efterhånden velafdækket gennem interview- og spørgeskemaundersøgelser, at læremidlerne er i brug i et relativt stort omfang (se fx Bueie, 2002; Skjelbred, 2003; Bachmann et al., 2003; DeCesare, 2007; Bundsgaard, Buch \& Fougt, 2017). Men hvordan læremidlerne faktisk bruges ude i klasselokalerne, er et underbelyst felt. Et review over international forskning af læremidler viser, at undersøgelser inden for feltet oftest begrænses til analyser af indhold og/eller form i læremidlerne. Der udføres sjældent klasserumsobservationer, hvor læremidlerne anvendes af lærere og elever (Knudsen, 2011). Empiriske undersøgelser i læremiddelbrug har længe været efterspurgt og bliver det stadig både nationalt og 
internationalt (Horsley \& Walker, 2005; Juuhl, Hontvedt \& Skjelbred, 2010; Christophe, Bock, Fuchs, Macgilchrist, Otto \& Sammler, 2018; Gabrielsen, Blikstad-Balas \& Tengberg, 2019). I et review efterspørges specifikt forskning i brug af læremidler inden for modersmålsundervisning (L1) ved brug af blandt andet klasserumsobservation (Gissel \& Buch, 2020, s. 117). Denne efterspørgsel bør tages til efterretning i forskningen, idet feltet ikke har tilstrækkelige bidrag, der har undersøgt den kompleksitet, som ligger i forholdet mellem læremiddel og læremiddelpraksis (Knudsen, 2011; Weinberg \& Wiesner, 2011). Kompleksiteten ligger bl.a. i, at læremidler kan betragtes som en indikator for, hvad der foregår i undervisningen, men der kan ikke sættes lighedstegn mellem forskning i læremidler og forskning i, hvordan læremidler bruges i en didaktisk praksis. Dertil er læremidler i hænderne på lærere og elever for uforudsigelig, idet læremidlet ikke dikterer, hvad der skal ske i et klasserum. Lærere og elever fortolker læremidlets didaktiske intentioner, og det bliver tilpasset til forskellige didaktiske kontekster. Disse forhold motiverede den empiriske undersøgelse af læremidler i brug, som præsenteres i det følgende.

Undersøgelsen bidrager med ny viden om spændingsfeltet mellem et læremiddel i sig selv, og hvordan det anvendes i en dynamisk skoleverden. Undersøgelsen er designet som et casestudie, hvor jeg videoobserverede to lærere i danskfagets litteraturundervisning i to 8. klasser henover fem uger. De to lærere havde oprindeligt valgt at arbejde med et læremiddel fra Danskfaget på Clios digitale fagportal (Danskfaget, u.å.). Lærerne vurderede imidlertid på et planlægningsmøde, at der var et for stort fokus på læseforståelse frem for kreative opgaver i forløbet. Derfor lod de sig kun inspirere af læremidlet. Dette var forventeligt i forhold til forskning i læremidler, hvor der generelt er enighed om, at lærere tilpasser læremidler efter behov (Bueie, 2003; Skjelbred, Solstad \& Aamotsbakken, 2004; Burkhauser \& Lesaux, 2007; Grossman \& Thompson, 2008; Watt, 2015; Gilje et al., 2016). I forlængelse af denne forskning blev det interessant at undersøge den kompleksitet, som er forbundet med læremidler i brug. I nærværende undersøgelse var formålet at skabe viden om situationen, hvor der er en lærer mellem læremidlet og klasserummet. Læreren foretager en vurdering af læremidlets anvendelsespotentiale og har i kraft af sin professionalisme og metodefrihed mulighed for at tilpasse læremidlet til specifikke formål på baggrund af vurderingen (se fx Dale, 1999; Schön, 2006; Hansen, 2010; Graf, Hansen \& Hansen, 2012). Undersøgelsen fokuserede derfor på lærernes didaktiske design, som blev produktet af inspirationen af læremidlet på Clio og 
indeholdte de opgaver, lærerne planlagde at bruge i undervisningen

Undersøgelsens vinkel udsprang af resultater fra forskningsprojektet Loeremidlernes danskfag (2017). Udgivelsen indeholder en kvantitativ opgørelse over, hvordan forskellige typer af indhold prioriteres i de mest anvendte læremidler i danskfaget. Ét af de bemærkelsesværdige resultater er den procentvise forskel på litteraturanalyse og-fortolkning. I udskolingen prioriteres litteraturanalyse højest i læremidlerne med 20\%, mens kun 8\% indebærer litteraturfortolkning (Bundsgaard, Buch \& Fougt, 2017, s. 39). Vi ved dog ikke ud fra denne undersøgelse, hvordan den procentvise fordeling er i en didaktisk praksis, eller hvordan litteraturanalyse og-fortolkning praktiseres i klasselokalerne, når der tages udgangspunkt i et læremiddel. På den baggrund blev denne undersøgelse opdelt i to delundersøgelser med følgende forskningsspørgsmål:

\section{Hvor stor en del af danskfagets litteraturundervisning i praksis udgør henholdsvis litteraturanalyse og litteraturfortolkning i en procentvis fordeling?}

\section{Hvordan praktiseres litteraturanalyse og litteraturfortolkning i litteratur-undervisningen?}

\section{Forskningsdesign og metodologi}

Undersøgelsens vinkel blev valgt ud fra den kvantitative opgørelse i Loeremidlernes danskfag (2017), hvor litteraturanalysen i læremidlerne er prioriteret højere end litteraturfortolkningen. Ud fra disse resultater undersøgte jeg derfor i første delundersøgelse, hvordan den procentvise fordeling var mellem litteraturanalyse og -fortolkning $\mathrm{i}$ en konkret læremiddelpraksis. Den procentvise fordeling havde til formål at give et overblik over prioriteringen af litteraturanalyse og -fortolkning i undervisningen - og netop ikke i læremidlerne. Men en ren kvantitativ undersøgelse kan udhule den kompleksitet, der ligger i praksis. Jeg inkluderede derfor en kvalitativ analyse i anden delundersøgelse. Denne havde til formål at give indsigt $\mathrm{i}$, hvordan litteraturanalyse og -fortolkning blev praktiseret i undervisningen.

1 Undersøgelsens forståelse af begrebet læremidler er afgrænset til didaktiske loeremidler som værende "produceret med henblik på undervisning i et bestemt indhold og derfor har en indlejret didaktik" (Hansen \& Skovmand, 2011, s. 19). 
Dette valg var baseret på en antagelse om, at litteraturanalysens høje procentdel i læremidlerne, og en eventuelt tilsvarende procentdel af tidsforbruget i litteraturundervisningen, ikke nødvendigvis udgør et problem. Derimod ser jeg et problem i, hvis litteraturanalysen bliver et mål i sig selv og løsrives fra litteraturfortolkningen (se fx Elf \& Hansen, 2017, s. 40). Når litteraturanalyse og -fortolkning lever i bedste velgående som kernebegreber i litteraturundervisningen bliver det interessant at undersøge, hvordan de to tilgange mødes i litteraturundervisningens praksis (se fx Rødnes, 2014).

Kombinationen af en kvantitativ og kvalitativ tilgang muliggjorde en kompleks analyse af en dynamisk praksis, hvor resultaterne komplementerede hinanden (Bryman, 2012; Klette, Blikstad-Balas \& Roe, 2017; Yin, 2018). Den kvantitative undersøgelse bidrog med et procentvist overblik og styrede, hvilke kvalitative nedslag i det empiriske materiale, der var væsentlige. På denne måde undgik jeg "cherry picking" i mit empiriske materiale, men på den anden side var procentopgørelserne dekontekstualiserede fra praksis (Snell, 2011, s. 256-257). Derfor ledsagede den kvalitative analyse med en nuanceret indsigt bag om tallene. Dette forhindrede, at de procentvise opgørelser kunne give anledning til vildledte fortolkninger, netop fordi de bagvedliggende årsager til tallene ikke kan ses i de procentvise opgørelser (Blikstad-Balas 2017, s. 517).

Empiriindsamlingen blev foretaget henover 24, lektioner à $45 \mathrm{~min}$. i første case (8.d) og 19 lektioner à $45 \mathrm{~min}$. i anden case (8.c). Klasserne arbejdede i dette tidsinterval med romanen Med ilden i ryggen af Martin Petersen (1999). I undersøgelsen fulgte jeg litteraturanalyse og -fortolkning igennem tre empiriske nedslag $\mathrm{i}$ litteraturundervisningen:

— Didaktiske designs: de to deltagende læreres videreudvikling af et undervisningsforløb fra den digitale fagportal Clio i et fælles didaktisk design til hver deres klasse.

- Undervisning: videoobservationer af litteraturundervisningen i begge klasser.

- Elevprodukter: elevprodukter i form af padlets, der indeholdt skriftlige elevbesvarelser af opgaver fra de didaktiske designs og spontant opståede opgaver i undervisningen.

Jeg vurderede, at litteraturundervisningens kompleksitet ikke kunne indfanges i et enkelt nedslag. Hvor et læremiddel er statisk, så er læremidler i brug dynamiske og befinder sig i komplekse kontekster, hvor lærere og elever anvender dem på forskellige måder. De tre empiriske nedslag bidrog med hver deres perspektiv på, 
hvordan litteraturanalyse og -fortolkning blev prioriteret og praktiseret. I de didaktiske designs kunne planlægningen af litteraturundervisningen iagttages. I videoobservationerne af litteraturundervisningen kunne gennemførelsen i den didaktiske praksis iagttages. I elevprodukterne kunne elevernes individuelle arbejde, gruppearbejde og lektier iagttages.

Der blev anvendt en gennemgående kodningsstrategi til analyse af de empiriske nedslag. Kodningen skabte retningen for min undersøgelse ved at være en analytisk optik, som begrænsede hvad jeg fik øje på, men samtidig holdte formålet med undersøgelsen klart (Klette, 2009, s. 74). Strategien muliggjorde endvidere systematisk sammenligning af cases (Mercer, 2010; Heath, Hindmarsh \& Luff, 2010) på tværs af litteraturdidaktiske praksisser. Kodningen blev udført med henblik på at adskille det empiriske materiale i håndterbare enheder på en sådan måde, at jeg både kunne måle den procentvise fordeling af litteraturanalyse og -fortolkning (1. delundersøgelse) samt udføre en finmasket analyse af praktiseringen (2. delundersøgelse).

\section{Videnskabsteoretisk forankring}

I det følgende vil jeg præsentere min videnskabsteoretiske forankring i hermeneutikken. Oftest placeres arbejdet med litteraturanalyse og -fortolkning inden for den hermeneutiske tradition i danskfaget, hvor der ses et spænd mellem danskfagets to hovedfløje: dansk som et hermeneutisk fag og dansk som et kommunikationsfag (Krogh, 2003; Hansen, 2016; Henkel, 2017). Begreberne litteraturanalyse og -fortolkning hører hjemme i danskfagets hermeneutiske fløj, hvor de litterære tekster befinder sig. De to begreber er principielt to forskellige størrelser i en alment accepteret forståelse: analyse er at opdele, og fortolkningen er at sætte delene sammen til en helhed (Kaspersen, 2012; Jørgensen, 2019). Dog er der en fælles anerkendelse af, at de i praksis flyder sammen i et dialektisk forhold, hvor vi fortolker hele tiden - vi forstår delene ud fra helheden og helheden ud fra delene i en hermeneutisk forståelse (Møller, Poulsen \& Steffensen, 2010). Den primære udfordring blev på baggrund af denne konstatering, at analyse og fortolkning indgår i en kompleks indbyrdes sammenhæng. Det blev præmissen for undersøgelsen, at jeg anerkendte samhørigheden mellem analyse og fortolkning, men at disse to begreber nødvendigvis måtte adskilles i en kodningssituation. Dette blev gjort for at kunne fokusere undersøgelsen af litteraturundervisningen på henholdsvis dele af teksten (analyse) og tekstens helhed (fortolkning). 
Ifølge Mogens Pahuss (2015) er de to centrale begreber i den hermeneutiske tænkning: fortolkning og mening, der viser sig i menneskelig aktivitet og produkterne af menneskelig aktivitet. I disse aktiviteter og produkter ligger en intention, der har et udtryk, som kan iagttages (Pahuus, 2015, s. 225-226). I denne undersøgelse var der konkret tale om didaktiske designs, undervisning og elevprodukter. I disse produkter/aktiviteter lå forskellige intentioner, hvis udtryk kunne iagttages: 1) De didaktiske designs repræsenterede lærernes planlagte intentioner om, hvordan undervisningen skulle se ud. 2) Aktiviteter under videoobservationer af undervisningen repræsenterede lærernes intentioner om, hvordan undervisningen skulle gennemføres (fx klassesamtaler og gruppearbejde). 3) Elevernes padlets repræsenterede (forhåbentligt) elevernes intentioner om at udvikle og vise danskfaglig formåen i et skriftligt produkt.

\section{Metode}

I det følgende vil jeg præsentere casestudiet som ramme for undersøgelsen. De anvendte metodiske tilgange var dokumentanalyse og videoobservation. Designet var et multipelt casestudie bestående af to cases i et komparativt casestudie (se Yin, 2018, s. 48). Ved det komparative studie blev der mulighed for at sammenligne resultaternes ensartethed for at kunne udlede generelle tendenser og lade resultaterne i de to cases udfordre hinanden (jf. Yin, 2018, s. 55). Der blev anvendt videoobservation i undersøgelsen for at muliggøre, at elevernes arbejde kunne genses i en høj detaljegrad (Klette, 2009, s. 64). Men selvom videoobservationerne gav overblik over store dele af klassens arbejde, kunne de ikke inkludere alt. Elevernes samtaler under gruppearbejdet og deres individuelle skriftlige arbejde var udfordrende at indfange. Jeg supplerede derfor med feltnoter under videoobservationerne for at opnå en højere detaljegrad (Tjora, 2012, s. 62). Det blev fx registreret, hvilke opgaver eleverne prioriterede at arbejde med, hvis der var mere end én mulig opgave. Denne tilgang understøttede mit kodningsarbejde, der krævede, at også det individuelle arbejde og gruppearbejdet blev medtaget så detaljeret som muligt.

Der blev i undersøgelsen anvendt dokumentanalyse af lærernes didaktiske designs og elevprodukter. Lærerne foretog ændringer i det fælles didaktiske design, som var produktet af inspirationen fra Clio. Derfor blev de to versioner analyseret hver for sig. De didaktiske designs som dokumenter bidrog til at udgøre empiri, som var et udtryk for lærernes planlægningsproces. Dermed kunne der inddrages et empirisk nedslag, der var et udtryk for 
lærernes planlægningsproces. Dermed kunne der inddrages et empirisk nedslag, der var et udtryk for det tidspunkt, hvor planlægningen foregik, som jeg ikke havde adgang til at observere (se fx Lynggaard, 2015, s. 156). Elevprodukterne som dokumenter havde en lignende funktion i undersøgelsen. Videoobservationerne og feltnoterne har i nogen grad indfanget elevernes skriftlige arbejde. Dog kom disse tilgange til kort i forhold til at få et nuanceret billede af elevernes arbejde. De varierende arbejdsformer i klassen og lektier i hjemmet kunne ikke inkluderes. Elevprodukterne bidrog derfor til at indfange elevernes individuelle arbejde og gruppearbejde i undervisningen samt deres lektier. Kort sagt bidrog dokumenterne til indsigt i perspektiver fra både før, under og efter gennemførelsen af undervisningen.

Tabel 1.

Empirioversigt.

\begin{tabular}{|c|c|c|}
\hline \multicolumn{3}{|l|}{ Empirioversigt } \\
\hline Didaktiske designs & Videoobservationer & Elevprodukter \\
\hline $\begin{array}{l}\text { Case 1: } 49 \text { delopgaver } \\
\text { Case 2: } 42 \text { delopgaver }\end{array}$ & $\begin{array}{l}\text { Case 1: } 24 \text { lektioner à } 45 \mathrm{~min} . \\
\text { Case 2: } 19 \text { lektioner à } 45 \mathrm{~min} .\end{array}$ & $\begin{array}{l}\text { Case 1: } 17 \text { padlets } \\
\text { Case 2: } 18 \text { padlets }\end{array}$ \\
\hline
\end{tabular}

\section{Det litteraturdidaktiske kodningssystem}

Til undersøgelse af de tre empiriske nedslag blev der anvendt en kvalitativ tematisk indholdsanalyse til kodning som strategi for datareduktion (Ramian, 2012, s. 124). Den metodiske fremgangsmåde definerer jeg som analytisk induktion, da arbejdsprocessen indebar en kombination af deduktion og induktion i en iterativ proces. Fremgangsmåden startede deduktivt, og der var vedvarende interaktion imellem arbejdsfaserne ${ }^{2}$ (se lignende beskrivelse af fremgangsmåde hos Klette, 2009, s. 69; Bryman, 2012, s. 297-298; Szulevicz, 2015, s. 93).

Undersøgelsens teoretiske analyseværktøj udspringer af taksonomibegrebet. Valget af en taksonomisk tænkning havde til hensigt at nuancere forståelsen af litteraturanalyse og -fortolkning

2 Kategoriseringen er baseret på Boolsens og Brymans afgrænsning af analytisk induktion (Boolsen, 2017, s. 30; Bryman, 2012, s. 566) og den iterative proces i arbejdet med kvalitative analyser (Boolsen, 2017, s. 49; Bryman, 2012, s. 566) 
ved at lade begreberne udfolde sig i en kontekst, hvor relaterede begreber fra litteraturundervisningen indgik i et samspil. Til afgrænsningen af taksonomiske niveauer anvendte jeg Benjamin Blooms taksonomi (1975) [1956], som i undersøgelsen er induktivt omformet til et litteraturdidaktisk kodningssystem. De induktivt udledte kategorier benævnes herfra som indholdskategorier ${ }^{3}$.

Blooms taksonomi tilbyder et anvendelsesorienteret klassifikationssystem til afgrænsning af seks taksonomiske hovedkategorier, der er underinddelt i subkategorier: 1) viden 2) forståelse, 3) anvendelse, 4) analyse, 5) syntes og 6) vurdering (Bloom, 1975, s. 16). De tre første repræsenterer de simple taksonomiske niveauer, og de tre sidste repræsenterer de komplekse taksonomiske niveauer. I Blooms klassifikation er der tale om uddannelsesmål, hvilket indebærer eksplicitte formuleringer, der henviser til, hvad den lærende bør lære (Bloom, 1975, s. 12; 26). Jeg kodede ikke direkte mål for undervisningen ( $\mathrm{fx}$ kompetencemål), men lærerens intention om at ramme et bestemt taksonomisk niveau, som det kom til udtryk i opgaver, aktiviteter eller lærerens spørgsmål (se lignende anvendelse af Blooms taksonomi hos: Tarman \& Kuran, 2015; Walsh, Bowes \& Sweller, 2017; Köksal \& Ulum, 2018).

Indholdskategorierne opstod i et samspil mellem teori og empiri. Empirien var styrende for, hvilke taksonomiske niveauer der viste sig fra Blooms taksonomi, og hvilke teoretiske perspektiver som blev relevante at supplere yderligere med. Eksempelvis viste Blooms hovedkategorier anvendelse og vurdering sig ikke i analysen af empirien. Disse blev derfor ikke inkluderet. Kunne en opgave- og/ eller spørgsmålstype ikke identificeres i Blooms taksonomi, blev der valgt en alternativ definition (eksempelvis elevens erfaringsverden og perspektivering). Kodningssystemet blev dermed udviklet hen over flere faser i undersøgelsen, og kodningssystemet blev et produkt af hele undersøgelsesprocessen. I nedenstående liste bliver hver indholdskategori overordnet illustreret:

3 Begrebet indholdskategori dækker over mine induktivt udledte kategorier. Hoved- og subkategori refererer til den forståelse, jeg henter deduktivt fra Blooms taksonomi. 
Tabel 2.

Oversigt over indholdskategorier.

\begin{tabular}{|c|c|c|}
\hline Indholdskategori & Kendetegn & Eksempel \\
\hline Elevens erfaringsverden & $\begin{array}{l}\text { Kendetegnet er elevernes } \\
\text { umiddelbarhed og personlige } \\
\text { erfaringer (Nielsen, 2006, s. 265). }\end{array}$ & Hvad ville du gøre, hvis... \\
\hline Viden & $\begin{array}{l}\text { Kendetegnet er at kunne huske } \\
\text { (Bloom, 1975, s. 62). }\end{array}$ & $\begin{array}{l}\text { Hvad hedder } \\
\text { hovedpersonen? }\end{array}$ \\
\hline Forståelse & $\begin{array}{l}\text { Kendetegnet er at kunne forstå, } \\
\text { hvad der bogstaveligt bliver } \\
\text { kommunikeret (Bloom, 1975, s. 89). }\end{array}$ & Skriv et resumé af kapitel 3. \\
\hline Analyse & $\begin{array}{l}\text { Kendetegnet er at et givent } \\
\text { materiale nedbrydes i dele og } \\
\text { samles igen ved at udpege relationer } \\
\text { mellem delene, og hvordan disse er } \\
\text { organiseret (Bloom, 1975, s. 144). }\end{array}$ & $\begin{array}{l}\text { Lav en person-karakteristik } \\
\text { af... }\end{array}$ \\
\hline Fortolkning & $\begin{array}{l}\text { Kendetegnet er at dele sættes } \\
\text { sammen, så der fremkommer en } \\
\text { helhed af mening, der ikke var } \\
\text { tydelig før (Bloom, 1975, s. 162). }\end{array}$ & $\begin{array}{l}\text { Hvilke temaer er der i } \\
\text { bogen? }\end{array}$ \\
\hline Perspektivering & $\begin{array}{l}\text { Kendetegnet er at hæve teksten op } \\
\text { og perspektivere fortolkningen til } \\
\text { tekstens omverden (Elf \& Hansen, } \\
\text { 2017, s. 42). }\end{array}$ & $\begin{array}{l}\text { Hvilke forskelle og } \\
\text { ligheder... }\end{array}$ \\
\hline
\end{tabular}

På baggrund af kodningen arbejdede jeg derfor med i alt seks overordnede indholdskategorier: elevens erfaringsverden, viden og forståelse (de simple taksonomiske niveauer) analyse, fortolkning og perspektivering (de komplekse taksonomiske niveauer). Hver af Blooms hovedkategorier indeholder et varierende antal subkategorier. De ledsagende temaer i kodningssystemet blev induktivt udledt på baggrund af disse. Fx har hovedkategorien analyse følgende subkategorier: analyse af elementer, analyse af relationer og analyse af organisatoriske principper. Disse blev i kodningsprocessen navngivet efter danskfaglige begreber. Eksempler på dette er tidslinje, personkarakteristik og aktantmodel. Herunder illustreres de seks indholdskategorier sammen med de ledsagende temaer, som fremkom induktivt under kodningen: 


\section{Figur 1.}

Oversigt over temaerne i de seks

indholdskategorier.

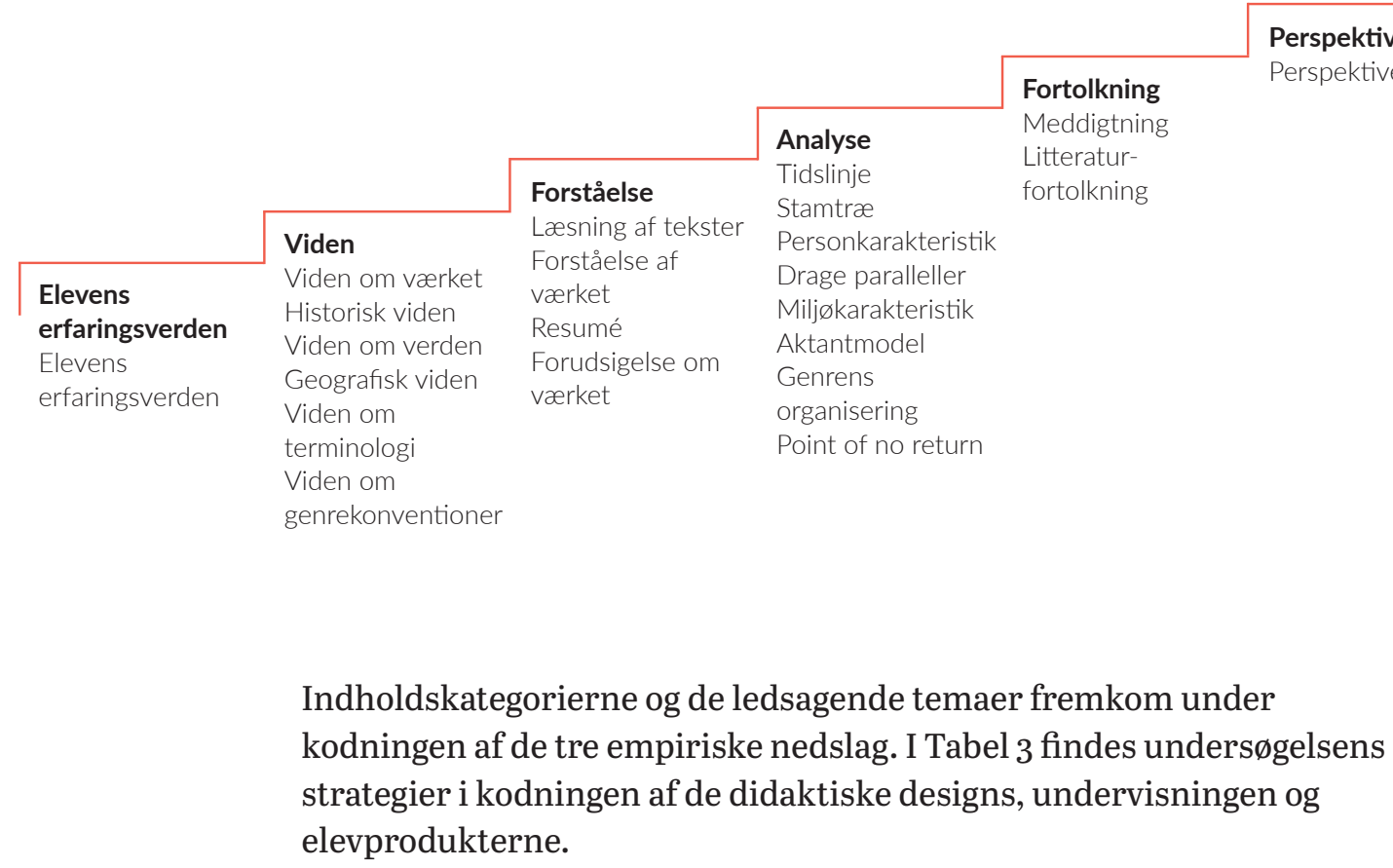

Tabel 3.

Oversigt over kodningsstrategier.

\begin{tabular}{l|l} 
Empirisk nedslag & $\begin{array}{l}\text { Kodningsstrategi } \\
\text { Didaktiske designs }\end{array}$ \\
$\begin{array}{l}\text { Kodningen blev udført på opgaver, som } \\
\text { lærerne havde en intention om at inkludere i } \\
\text { undervisningen. }\end{array}$ & $\begin{array}{l}\text { Der udført kodning af delopgaver i de to } \\
\text { blev adskilt i de tilfælde, hvor opgaver var } \\
\text { sammensat af flere spørgsmål eller anvisninger. }\end{array}$ \\
\hline $\begin{array}{l}\text { Undervisning } \\
\text { medningen blev udført på } \\
\text { videoobservationerne. }\end{array}$ & $\begin{array}{l}\text { Der blev udført kodning af den tid, hvor } \\
\text { der foregik danskfaglighed (den effektive } \\
\text { undervisningstid). Sekvenser i kodningen blev } \\
\text { rammesat efter indholdskategorierne, hvor } \\
\text { en ny sekvens startede, når læreren flyttede } \\
\text { sig fra ét niveau i taksonomien til et andet i } \\
\text { en klassesamtale. Derudover blev individuelt } \\
\text { arbejde og gruppearbejdet kodet efter, hvilke } \\
\text { taksonomiske niveauer de igangsatte opgaver } \\
\text { indebar. }\end{array}$ \\
\hline $\begin{array}{l}\text { Elevprodukterne } \\
\text { Kodningen blev udført på besvarelser fra }\end{array}$ & $\begin{array}{l}\text { Der blev udført kodning af indholdet i } \\
\text { elevernes besvarelser på padlets. Opgaverne } \\
\text { blev kodet efter, hvorvidt eleven havde } \\
\text { forsøgt at løse en opgave inden for et givent } \\
\text { taksonomisk niveau. }\end{array}$ \\
\hline
\end{tabular}




\section{Resultater fra første delundersøgelse}

Først vil jeg præsentere resultaterne fra første delundersøgelse.

Det gøres op, hvor stor en del af litteraturundervisning i de to cases, der blev udgjort af henholdsvis litteraturanalyse og -fortolkning i en procentvis fordeling. Lærerne forankrede sig primært i deres fælles design med få variationer og fulgte den planlagte progression. Men selvom dette var tilfældet, prioriterede lærerne indholdskategorierne forskelligt alt efter hvilket empirisk nedslag, der betragtes. Den procentvise fordeling af indholdskategorierne i case 1 og 2 illustreres herunder i en sammenligning af de tre empiriske nedslag (didaktiske designs, undervisningen, elevprodukter):

Figur 2.

Sammenligning af indholdsfordeling - didaktisk design, den effektive undervisningstid og elevprodukter (case 1).

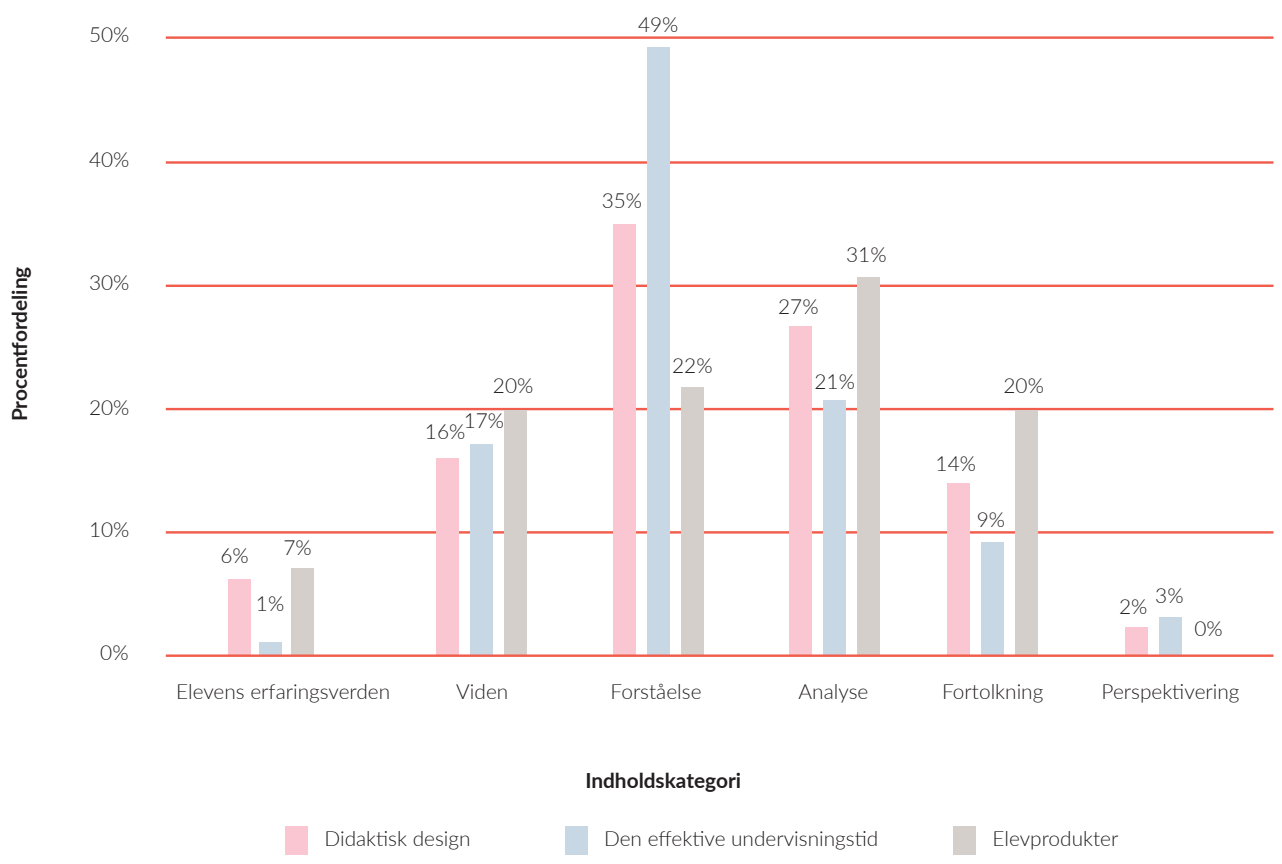


Figur 3.

Sammenligning af indholdsfordeling - didaktisk design, den effektive undervisningstid og elevprodukter (case 2).

$50 \%$

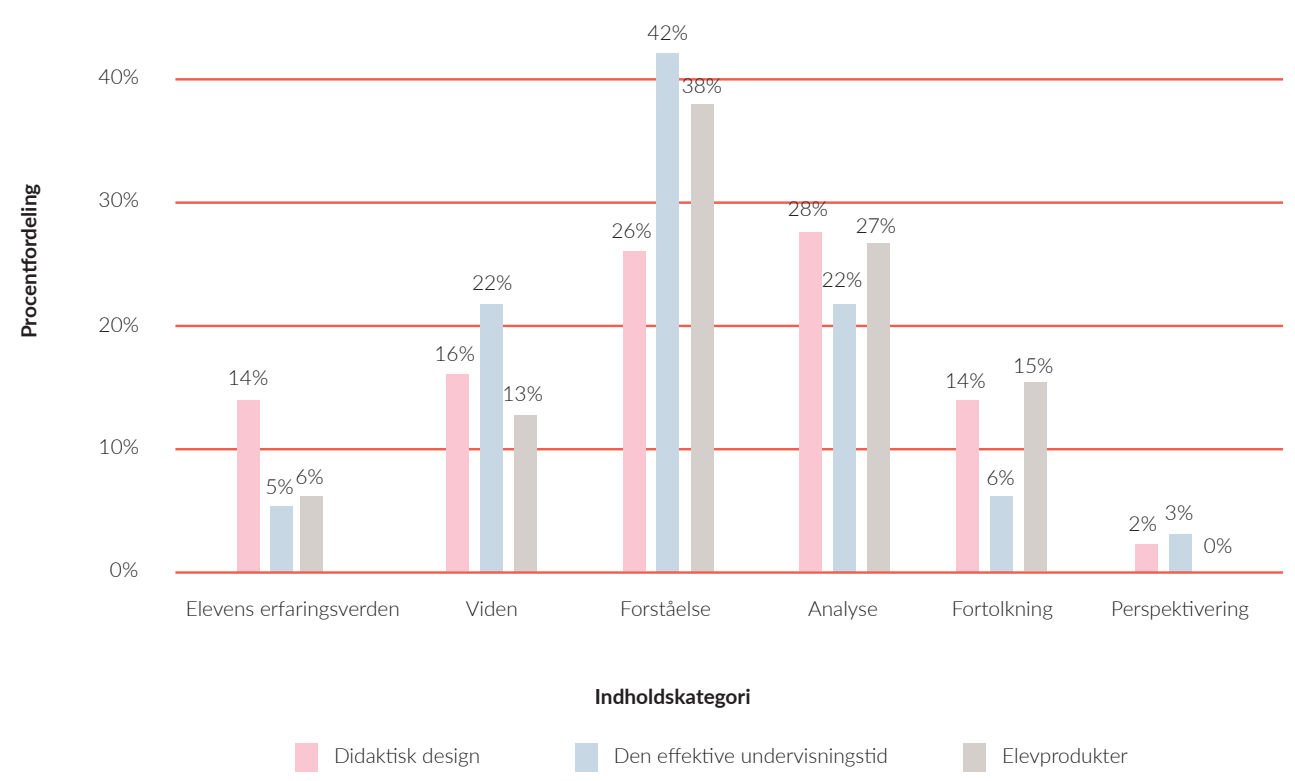

De simple taksonomiske niveauer i den procentvise fordeling Indholdskategorierne fra den simpleste halvdel af de taksonomiske niveauer er: elevens erfaringsverden, viden ogforståelse. I de didaktiske designs udgør de simple niveauer tilsammen $57 \%$ i case 1 og $56 \%$ i case 2. I den effektive undervisningstid udgør de $67 \%$ i case 1 og $69 \%$ i case 2. I elevprodukterne udgør de $49 \%$ i case 1 og $57 \%$ i case 2 . Inden for de simple taksonomiske niveauer i begge cases havde lærerne i alle tre empiriske nedslag prioriteret elevens erfaringsverden lavest. Viden blev prioriteret højere, og forståelse blev prioriteret højest. Disse resultater viser, at en betydelig del af litteraturundervisningen bestod $i$ at opbygge et fundament for de komplekse niveauer. Før og under analyse- og fortolkningsarbejdet i litteraturundervisningen blev der dermed praktiseret arbejde inden for andre indholdskategorier i et rigt omfang. 
De komplekse taksonomiske niveauer i den procentvise fordeling

Indholdskategorierne fra den komplekse halvdel af de taksonomiske niveauer er: analyse, fortolkning og perspektivering. I de didaktiske designs udgør de komplekse niveauer tilsammen $43 \%$ i case 1 og $44 \%$ i case 2. I den effektive undervisningstid udgør de $33 \%$ i case 1 og $31 \%$ i case 2. I elevprodukterne udgør de $51 \%$ i case 1 og $41 \%$ i case 2 . Disse resultater viser, at de komplekse taksonomiske niveauer generelt blev prioriteret lavere end de simple taksonomiske niveauer. De to cases viser samme tendenser i den procentvise fordeling af de komplekse taksonomiske niveauer: Lærerne havde i alle tre empiriske nedslag prioriteret perspektivering lavest. Fortolkning blev prioriteret højere, og analyse blev prioriteret højest. Et påfaldende resultat er, at det blev prioriteret højere, at analytiske og fortolkningsmæssige opgaver blev inkluderet skriftligt i padletten fremfor at blive gjort til genstand for diskussion i den effektive undervisningstid. Et andet bemærkelsesværdigt resultat var, at perspektivering var den eneste af indholdskategorierne, hvor der kunne ses en fuldstændig overensstemmelse mellem de to cases i alle tre procentvise opgørelser af de empiriske nedslag. Derudover var perspektivering også den eneste af de seks indholdskategorier, der udgik i elevprodukterne.

\section{Resultater fra anden delundersøgelse}

I præsentationen af resultaterne fra anden delundersøgelse, fokuserer jeg på undersøgelsens vigtigste fund. I de tre empiriske nedslag (didaktiske designs, undervisningen, elevprodukter) tegner undersøgelsens resultater et billede af, hvordan analyse og fortolkning blev praktiseret i litteraturundervisningen i de to cases.

\section{Analyse og fortolkning blev praktiseret adskilt fra hinanden og fra de resterende indholdskategorier i hver deres vakuum}

Mine resultater fra den tematiske analyse peger på, at analyse og fortolkning var de to eneste indholdskategorier ud af de seks, der både blev praktiseret adskilt fra hinanden og fra de resterende indholdskategorier. I kodningen viste dette sig i de få korte klassesamtaler, der omhandlede analyse og fortolkning. Fx var en klassesamtale mellem læreren og eleverne om en analytisk opgave opbygget af lærerstillede spørgsmål, der var kodet med temaer fra indholdskategorien analyse. Læreren brugte tre et halvt minut på at notere en opsamling på tavlen over, hvilke karakterer fra romanen, der var på stamtræet indtil videre og noterede elevernes indspark løbende. I en anden situation udfyldte en af klasserne en aktantmodel for en af romanens bipersoner under en klassesamtale som stilladsering for, 
at eleverne individuelt kunne udfylde en aktantmodel over hovedpersonen efterfølgende. Ingen af de to aktantmodeller blev dog taget op til diskussion.

Det samme var tilfældet for klassesamtaler om fortolkning, hvor der ikke optrådte lærerstillede spørgsmål, som blev kodet af temaer fra indholdskategorien analyse eller nogen af de resterende indholdskategorier - men kun med temaer fra indholdskategorien fortolkning. I den ene klasse brugte læreren tid på en klassesamtale, der omhandlede romanens tema. Læreren spurgte eleverne: "Hvad er temaerne i denne her bog?" De elever, der deltog, svarede med op til tre forslag til, hvilke temaer der kunne være tale om (eksempelvis krig, flugt, familie, kærlighed, sorg). Der var tale om en runde blandt eleverne med bud på temaer og ikke en undersøgende samtale, der blev uddybet eller udfordret af læreren eller andre elever. Analysen kvalificerede dermed ikke diskussionen aktivt om romanens tematisering og fortolkningen blev ikke sat til genstand for diskussion.

Der opstod et vakuum i analysen og fortolkningen, hvor de to kategorier blev praktiseret hver for sig uden støtte fra de andre indholdskategorier eller fra hinandens. Elevens erfaringsverden, viden og forståelse blev dermed ikke anvendt til at løse analytiske og fortolkningsmæssige opgaver og indgik stort set ikke som støttende i de få korte klassesamtaler, der havde analyse og fortolkning som fokus.

Indholdskategorien viden trækker dog også primært på temaer fra sin egen indholdskategori under klassesamtaler, lige som det var tilfældet med analyse og fortolkning. Eksempelvis spurgte den ene lærer ud i klassen: "Hvad er forskellen på lov og ret?" Én elev definerede det som: "Ret kan være en menneskeret, eller man kan have ret", og en anden elev bød ind med: "[hovedpersonen] har ret, men loven siger noget andet". Senere gik samtalen på viden om strafferammer, hvor læreren spurgte: "Hvad laver onkel Klaus?" En elev svarede, at han hjælper flygtninge med at flygte. Læreren fortsatte: "Hvad kalder man dem, der hjælper flygtninge med at flygte over grænsen?" En elev svarede "smugler". Læreren indsnævrede definitionen med det næste spørgsmål: "Hvilken slags smugler er der tale om?" og en elev svarede "menneskesmugler". Efterfølgende bad læreren eleverne om at gå på internettet og finde ud af, hvad straffen er for at være menneskesmugler. I disse eksempler udvides elevernes viden for at forstå romanen mere dybdegående ved at definere lov og ret samt strafferammer. Opgaverne er oplagte som grundlag for en etisk diskussion om de handlinger, som karaktererne i romanen vælger. Dog tages denne viden ikke i brug i samtaler af mere abstrakt karakter. Elevernes viden har med andre ord ikke andet formål end viden i sig selv om isolerede begreber. 
Forskellen mellem indholdskategorien viden og indholdskategorierne analyse ogfortolkning er, at tematikker fra indholdskategorien viden også fandtes hyppigt i samspil med andre indholdskategorier i kodningen. I en klassesamtale fungerede viden som supplerende for elevernes forståelse af passager fra romanen. Fx bad den ene lærer eleverne om at finde passagen øverst på side $140 \mathrm{i}$ romanen, og en elev læste den højt. Læreren stoppede eleven i oplæsningen efter få linjer og spurgte klassen med henvisning til teksten: "Total kapitulation. Hvad betyder det? Hvad gør man, når man kapitulerer?" En elev svarede, at man kaster sig ned for sikkerhed. En anden elev definerede det anderledes ved at forklare, at det betyder at overgive sig. Læreren hjalp eleverne med at afklare ordets korrekte betydning efter eleverne havde givet deres svar. I denne situation understøttede viden om begreber læseforståelsen og indgik naturligt i at forstå bogstaveligt, hvad romanen handlede om.

Dette var ikke tilfældet for analyse og fortolkning, som ikke optrådte understøttende for hinandens indholdskategorier eller for andre indholdskategorier. Dette betyder ikke nødvendigvis, at analyse og fortolkning er isolerede kategorier i elevernes bevidsthed og ikke bidrager til, at eleven kan se værket som en helhed på baggrund af opgaveløsning og klassesamtaler. Dette kan jeg ikke udtale mig om på baggrund af empirien. Men det vidner om, at det forventedes, at eleverne i høj grad selv var i stand til at lave koblingen mellem analyse og fortolkning, uden at læreren eksplicit pegede på det igennem spørgsmål og opgaver. Dette afføder spørgsmålet, om denne tilgang til litteraturundervisningen risikerer at stivne i metodisk formalisme ved, at eleverne laver besvarelser af lærerens udvalgte analytiske opgaver, uden at besvarelserne inkluderes i en fortolkning. Når de analytiske opgaver ikke benyttes eksplicit til at vise sammenhænge i værket, risikerer analysen at blive et mål i sig selv.

Indholdskategorien perspektivering adskiller sig fra analyse og fortolkning ved at trække på tematikker fra indholdskategorierne i den simple halvdel af de taksonomiske niveauer under klassesamtaler. Dette fremkom fx i kodningen ved, at en klassesamtale, der omhandlede perspektivering, indeholdt understøttende spørgsmål fra lærerne, der var tematiseret som viden og forståelse. Klassen havde set mini-dokumentaren Sharaf, men før de perspektiverende spørgsmål blev igangsat, spurgte læreren ud i klassen: "Hvad er [hovedpersonen fra romanen] flygtet fra?" En elev svarede "dårlige forhold". Læreren forsøgte at få mere dybde i svaret ved at spørge yderligere ind: "Hvad var det for nogle forhold, der var dårlige?" og eleven svarede, at der var tale om de politiske forhold. Læreren forsøgte at få flere perspektiver i spil ved at spørge igen: "Hvad flygter Klaus fra?" hvortil flere elever bød ind med svar, der handlede 
om krig og at ville redde sine søskende. Først efter at dette var etableret, gik læreren videre til perspektiverende spørgsmål, hvor den efterfølgende klassesamtale omhandlede forskelle og ligheder mellem hovedpersonen i romanen og hovedpersonen i dokumentaren. I denne situation aktiverede læreren perspektiveringen ved at bede eleverne om at huske, hvad de vidste og havde forstået om romanen, før der blev stillet perspektiverende spørgsmål. Dette var sjældent tilfældet med indholdskategorierne analyse og fortolkning. Desuden var det overraskende, at analyse og fortolkning ikke havde en plads sammen med perspektivering. Perspektivering foregår efter arbejdet med værket i sig selv, hvor man hæver sig over teksten og ser verden omkring den (eksempelvis i forhold til samfundet eller andre tekster). I undervisningen blev analysen og fortolkningen ikke anvendt til at se teksten i forhold til omverdenen, men det gjorde viden og forståelse.

\section{Analyse og fortolkning blev praktiseret under individuelt arbejde, gruppearbejde og som lektier}

Analyse og fortolkning blev ikke udbredt praktiseret i klassens fællesskab. Dette kunne iagttages i kodningen ved, at eleverne oftest arbejdede med analyse- og fortolkningsopgaver som individuelt arbejde eller gruppearbejde. Eleverne færdiggjorde disse opgaver som lektie. I den ene klasse arbejdede eleverne eksempelvis individuelt med personkarakteristikker i ca. 23 minutter, imens der var ro i klasselokalet. I den anden klasse kunne eleverne vælge i mellem at lave personkarakteristikkerne individuelt eller i grupper, så længe eleverne noterede deres besvarelse på den individuelle padlet.

I forhold til opsamling på lektier, bad læreren fx eleverne om at finde deres billeder frem på padletten af flygtningelejren Granhuse i starten af en lektion. Billederne repræsenterede en miljøkarakteristik, hvor eleverne havde tegnet en skitse over lejren, baseret på informationer fra romanen om, hvordan denne var opbygget (se Figur 4 øverst i anden kolonne). Læreren tog en hurtig runde blandt eleverne og kiggede kortvarigt på tegningerne. Fem elever viste deres tegninger på den digitale tavle for resten af klassen. Situationen tog $i$ alt fem et halvt minut, og elevernes valg blev ikke taget op til diskussion, og skitserne fungerede kun illustrativt. 
Figur 4.

Eksempel på elevprodukt på padlet (uddrag).

\begin{tabular}{|c|c|c|c|c|c|}
\hline $\begin{array}{l}\text { Brev til Klaus' } \\
\text { far } \\
\text { Kære far. } \\
\text { Hvordan har du det? } \\
\text { Hvor er du? Lever } \\
\text { du overhovedet? } \\
\text { Hvis du læser dette } \\
\text { brev, skal du vide, } \\
\text { at vi savner dig. } \\
\text { vi er i Danmark, i } \\
\text { sikkerhed. } \\
\text { Vi har alle været } \\
\text { igennem mange svære } \\
\text { og mærkelige ting } \\
\text { gennem det sidste } \\
\text { halve år.....Men mon } \\
\text { ikke du ogsă har } \\
\text { det? } \\
\text { Som jeg lovede dig } \\
\text { derhjemme, har jeg } \\
\text { gjort mit bedste } \\
\text { for at passe på } \\
\text { hele familien.... } \\
\text { Her for tiden går } \\
\text { jeg i skole, hvor } \\
\text { vi læser, skriver } \\
\text { og synger. Mor er } \\
\text { tit på systuen } \\
\text { eller snakker med } \\
\text { de andre voksne. }\end{array}$ & 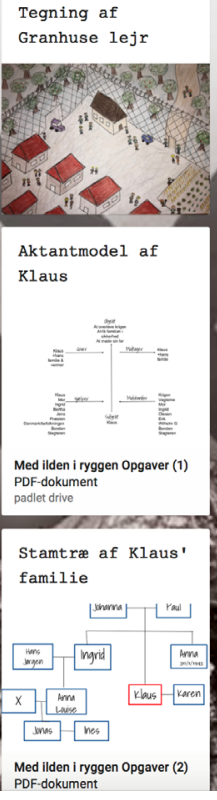 & $\begin{array}{l}\text { Paralleller } \\
\text { mellem } \\
\text { Juleevangeliet og } \\
\text { Klaus' situation } \\
\text { Flugt og fødsel er } \\
\text { to ting, der begge } \\
\text { indgăr i băde } \\
\text { juleevangeliet og i } \\
\text { Med ilden i ryggen. } \\
\text { i Juleevangeliet } \\
\text { flygter Josef og } \\
\text { Maria fra Nazeret } \\
\text { til Betlehem, hvor } \\
\text { Maria føder Jesus. } \\
\text { I Med ilden i } \\
\text { ryggen er Klaus og } \\
\text { hans familie pă } \\
\text { flugt fra krigen, } \\
\text { og Ingrid føder et } \\
\text { barn. }\end{array}$ & $\begin{array}{l}\text { “Først } i \text { det } \\
\text { øjeblik er krigen } \\
\text { forbi for mig” } \\
\text { Hvad mener Klaus? } \\
\text { Klaus havde lovet } \\
\text { sin far, at han } \\
\text { ville passe godt på } \\
\text { familien. Da han } \\
\text { for første gang i } \\
\text { lang tid er sammen } \\
\text { med sin far igen, } \\
\text { fắr Klaus endelig } \\
\text { muligheden for at } \\
\text { fortælle om Annas } \\
\text { død. Udover det fár } \\
\text { Klaus også vist sin } \\
\text { far den ske, som } \\
\text { han har passet } \\
\text { rigtig godt på. } \\
\text { Klaus har stor } \\
\text { skyldfølelse over } \\
\text { Annas død. Til } \\
\text { gengæld er han } \\
\text { stolt over at kunne } \\
\text { give sin far } \\
\text { sølvskeen. Da faren } \\
\text { svarer tilbage, at } \\
\text { alt nok skal gå, } \\
\text { stoler Klaus på } \\
\text { ham. }\end{array}$ & $\begin{array}{l}\text { Del } 3 \text { - } \\
\text { Afslutningen } \\
\text { Titlens betydning } \\
\text { Rent geografisk } \\
\text { krydiser Klaus og } \\
\text { hans familie } \\
\text { gransen til } \\
\text { Tyskland. Men ved } \\
\text { at gøre dette } \\
\text { krydser de ogsá } \\
\text { gransen til noget } \\
\text { helt nyt. De er } \\
\text { tilbage i deres } \\
\text { gamle hjemland, men } \\
\text { intet ser ud eller } \\
\text { er som før. } \\
\text { Temaer } \\
\text {-Kærlighed } \\
\text { Kærligheden mellem } \\
\text { Klaus og hans } \\
\text { familie fylder } \\
\text { meget i denne } \\
\text { historie, ogsá } \\
\text { selvom de flere } \\
\text { gange bliver } \\
\text { splittet fra } \\
\text { hinanden pá kryds } \\
\text { og tværs. } \\
\text { Derudover bliver }\end{array}$ & $\begin{array}{l}\text { Hvorfor hedder } \\
\text { bogen Med ilden i } \\
\text { ryggen? } \\
\text { Jeg tror, at titlen } \\
\text { Med ilden i ryggen } \\
\text { skal symbolisere } \\
\text { flugten. Ilden } \\
\text { betegner krigen, } \\
\text { som hele tiden } \\
\text { ligger lige bag } \\
\text { dem, og som de } \\
\text { bliver nødt til a } \\
\text { flygte fra for at } \\
\text { overleve. }\end{array}$ \\
\hline
\end{tabular}

Elevernes padlets (se Figur 4, eksempel på uddrag) repræsenterede nogle af besvarelserne fra elevernes arbejde under forløbet. Ikke alle opgaver fra forløbet var inkluderet. I nogle tilfælde måtte eleverne vælge mellem flere opgaver fra det didaktiske design til padletten, og andre gange blev en opgave kun besvaret mundtligt på klassen. I få tilfælde blev en opgave valgt fra pga. tidsnød i undervisningen. Enkelte gange opstod der nye opgaver spontant $\mathrm{i}$ undervisningen, som ikke oprindeligt var en del af det didaktiske design. Fx blev eleverne i den ene klasse bedt om, at lave et interview med et familiemedlem, som kunne huske begivenheder fra 2. verdenskrig. Eleverne skulle inkludere interviewet på deres padlet. Dette vidner om, at selvom det didaktiske design i vid udstrækning blev fulgt, var der ikke tale om en minutiøs gennemgang. Der var rum til omprioritering, når situationen indbød til det. Lærerne prioriterede forskelligt i forhold til, hvilke opgaver der skulle lægges ind på padletten. Eksempelvis prioriterede den ene lærer opgaver om viden højere end den anden, og det samme var tilfældet for forståelse. Et bemærkelsesværdigt fund i elevernes padlets var fraværet af perspektiverende opgaver. Perspektivering var den eneste af indholdskategorierne, som klassen udelukkende arbejdede med i fællesskab.

Opsamlende viser resultaterne, at viden, forståelse og 
perspektivering primært blev prioriteret som det, klassen skulle være fælles om under klassesamtaler. Derimod var elevens erfaringsverden, analyse og fortolkning prioriteret i de skriftlige elevprodukter og oftest ikke i fællesskabet. Analyse og fortolkning blev dermed prioriteret forskelligt alt efter hvilket empirisk nedslag, der blev iagttaget. Da indholdsfordelingen af analyse og fortolkning i vid udstrækning stemmer overens mellem de didaktiske designs og elevprodukterne peger det på, at analyse og fortolkning foregik. Dog blev de prioriteret højest i form af skriftlige besvarelser. Det interessante var, at analyse og fortolkning spillede en mindre rolle i undervisningstiden, og oftest var fraværende i klassesamtaler.

\section{Analyse og fortolkning blev praktiseret i korte opsamlinger på klassen og stod sjældent til genstand for diskussion}

I undervisningstiden læste eleverne deres analytiske og fortolkningsmæssige besvarelser op på tur, og eventuelt fulgte læreren op med en kort respons. Analyse og fortolkning stod derfor ikke i udbredt grad til genstand for diskussion. Eksempelvis havde den ene lærer valgt, at nogen af eleverne skulle vise deres padlets i slutningen af forløbet på klassen. Dette foregik ved, at fem elever blev udvalgt ved lodtrækning til at præsentere deres færdige produkt på klassens digitale tavle. Eleverne udvalgte selv fem punkter fra deres individuelle padlet, som de viste og gennemgik. Under deres præsentationer stillede læreren få opklarende spørgsmål inden ordet blev givet videre til den næste elev. Elevernes arbejde blev vist og gennemgået som et færdigt produkt, der ikke stod til genstand for diskussion og refleksion i fællesskabet.

Det mest bemærkelsesværdige fund i kodningen af videoobservationerne var, at forståelse dominerede undervisningstiden. Dette var på bekostning af analyse og fortolkning, som er litteraturundervisningens kernebegreber. Det var især klassesamtalerne, der sprang i øjnene. Klassesamtaler bestod primært af lærerstillede spørgsmål, som var kodet med temaer fra de tre simple taksonomiske niveauer og med fokus på forståelse. I en klassesamtale på 23 minutter anvendte den ene lærer fx elevernes resuméer fra flere af romanens kapitler som afsæt for samtale. Når en elev havde læst sit resumé op for klassen, spurgte læreren ind til kapitlet ved at inkludere hele klassens input. Fx spurgte læreren ind til, hvem der rejste med hovedpersonen i hestevognen, og hvor mange mennesker der rejste sammen. Eleverne nåede hen til resuméet, der gengav, at hovedpersonen blev slået af sin mor. Læreren spurgte ind til, hvorfor eleverne troede, at han blev slået og inddrog deres egen erfaringsverden ved at stille spørgsmålet: "Hvem er den 
skrappe hjemme hos jer. Far eller mor?" Flere af drengene råbte samstemmigt "MOR!" og efterfølgende fortalte læreren kortvarigt om opdragelsesmetoder. På denne måde inddrog læreren både viden om specifikke forhold i romanen og elevernes egen erfaringsverden for at fremme deres forståelse af romanens indhold. Dette peger på, at lærerne prioriterede et forståelsesfællesskab højt frem for et fortolkningsfællesskab. At dette var tilfældet i klassesamtalerne vidner om, at de simple taksonomiske niveauer var noget, klassen burde få styr på sammen. Alle skulle være med og have det grundlæggende på plads - og det gjorde klassen i fællesskab. Dermed blev det ikke prioriteret at skabe mening igennem analyse og fortolkning af værket, men at skabe mening gennem forståelse af værket. Med andre ord blev elevernes analyse og fortolkning ikke udfordret eller udbygget - det gjorde deres forståelse til gengæld.

Resultaterne viser samlet set, at der ikke i udbredt grad arbejdes med direkte relationer mellem analyse og fortolkningen eller de to kernebegrebers relationer til de resterende indholdskategorier. Dermed ikke sagt, at eleverne ikke kan lave koblingerne på egen hånd. Jeg kan kun antage, at koblingen foregår hos den enkelte elev, men min empiri kan ikke understøtte dette, da min tematiske analyse er begrænset til iagttagelser. Men eleverne havde gode muligheder for at lave koblingerne uden lærerens eksplicitte involvering. Dette fordi opgaverne i de didaktiske designs i høj grad lagde op til en progression, hvor opgaver fra de simple taksonomiske trin skulle understøtte de komplekse. En opgave fra de didaktiske designs lød fx som følger: "Find mindst 10 oplysninger om Wilhelm Gustloffs forlis". Wilhelm Gustloff var et tysk krydstogtskib, der blev overtaget af den tyske flåde som kaserneskib under 2. verdenskrig. I 1945 blev skibet torpederet af russerne, og over 7000 menneskeliv gik tabt, hvoraf størstedelen var tyske flygtninge (Ventegodt, 2017). Denne historiske begivenhed er medtaget i romanen, hvor læseren følger Klaus og hans lillesøster Anna under hele sejladsen. Under skibsforliset slipper Klaus Annas hånd, og hun glider ned i vandet og drukner. Men opgaven i det didaktiske design er i sig selv ikke sigende i forhold til begivenhedens funktion i værket. Den lægger udelukkende op til research af fakta om Wilhelm Gustloff og sættes ikke ind i en meningsfuld sammenhæng med værket. I et didaktisk design er dette en kontekstløs opgave, hvor eleven skal opnå viden om historiske forhold. Men i undervisningen giver opgaven mere og mere mening fra den er løst af eleverne i starten af forløbet til afslutningen af forløbet. Den historiske viden om skibsforliset bliver en måde at forstå hovedpersonen Klaus' situation på - forståelse for, hvad det gør ved et menneske at føle ansvaret for sin lillesøsters druknedød. Denne forståelse bliver nødvendig for, at eleverne kan lave en personkarakteristik, der giver et indblik i Klaus' 
udvikling som menneske fra en dreng, der leger krig, til en dreng, der oplever krig. Personkarakteristikken danner en del af grundlaget for at kunne danne en fortolkning af, hvad det betyder, når Klaus i slutningen af værket siger: "Først i det øjeblik er krigen forbi for mig”. Først dér kommer Klaus endelig tilbage til sin far i Tyskland og får lettet sit hjerte ved at fortælle om sin søsters død. Dette eksempel viser, hvordan en opgave på laveste taksonomiske niveau får betydning for, at eleverne gives mulighed for at bevæge sig op på de højere taksonomiske niveauer. Men når litteraturundervisningens kernebegreber analyse og fortolkning lukker om sig selv i

praktiseringen af dem, må der stilles spørgsmålstegn ved, om eleverne kan se koblingerne mellem de taksonomiske niveauer og kan bruge analysen med formålet at fortolke - frem for at analysen bliver et mål i sig selv.

\section{Diskussion - metodiske muligheder og begrænsninger}

Udfordringerne i undersøgelsen var særligt operationaliseringen af analyse og fortolkning, der skulle være målbare enheder i det litteraturdidaktiske kodningssystem. Jeg simplificerede to komplekse begreber, som i princippet er umålelige i den hermeneutiske tænkning. Taksonomi er blevet kritiseret for at underkende kompleksitet ved at bekende sig til et kumulativt hierarki (Furst, 1994, s. 34) og er derfor ikke direkte forenelig med de to begrebers dialektiske forhold. Men det var et nødvendigt onde at adskille de to begreber i en kodningssituation. Det blev antaget, at læreren satte noget $\mathrm{i}$ forgrunden og noget andet i baggrunden, og at dette kunne iagttages. Præmissen for undersøgelsen blev derfor, at læreren kan sætte analytiske opgaver og fortolkningsopgaver i henholdsvis forgrunden og baggrunden af litteraturundervisningen, hvor fokus er på ét af begreberne ad gangen. At analyse- og fortolkningsopgaver sættes i forgrunden eller baggrunden er ikke en underkendelse af, at eleven ikke tager den litterære teksts helhed i betragtning, imens eleven beskæftiger sig med en del af en litterær tekst. Derimod er det en antagelse om, at eleven undersøger en given litterær tekst med et primært fokus, der er sat af læreren. Læreren og eleverne kan ikke rette deres opmærksomhed mod alting på samme tid. Læreren vælger derfor at prioritere noget frem for noget andet i en undervisningssituation: Enten har læreren fokus på analyse eller fortolkning. Det læreren prioriterer at sætte i forgrunden, kan iagttages i form af fx valg af spørgsmål og opgaver. Denne prioritering antages at kunne kategoriseres ved, om et givent spørgsmål eller 
en given opgave retter sig mod henholdsvis analytiske dele eller en fortolkningshelhed ift. til den litterære tekst. Kodningsstrategien har derfor potentiale for finmasket analyse af en dynamisk danskundervisning på trods af de to begrebers dialektiske forhold. De induktivt udledte temaer har bidraget til en nuanceret forståelse af, hvad der sker i den didaktiske praksis på trods af den berettigede kritik.

De procentvise og tematiske opgørelser er et udtryk for de to specifikke cases, som blev undersøgt. Det er derfor ikke muligt at generalisere på baggrund af undersøgelsen. Dog er der stadig styrker i mindre casestudier. Casestudiet var velegnet til at indfange den komplekse kontekst (se fx Flyvbjerg, 2015), hvori læremidler befinder sig sammen med lærere og elever, der præger læremidlets vej fra planlægning af undervisning til gennemførelse af undervisning. Dog bør man være opmærksom på, at ved et skift til nye cases vil der højest sandsynligt opstå andre, samt flere eller færre indholdskategorier og temaer ved at anvende samme metodiske fremgangsmåde som i denne undersøgelse. De valgte kategorier blev dermed afgørende for, hvad jeg fik øje på i praksis og kan kritiseres for at være subjektive og udfordrende at gentage i nye cases (Boolsen, 2017, s. 113: Bryman, 2012, s. 289-290). Dog er Blooms taksonomi en tilpas generel kategorisering til, at denne vil kunne anvendes i andre casestudier. Men procentandelene og temaerne vil højst sandsynlig blive anderledes. Det er muligt, at eksempelvis forståelseskategorien bliver langt mindre, da en novelle på to sider kan læses som en del af elevens egen forberedelse før undervisningen påbegyndes i et nyt casestudie. Dermed vil læsning ikke indgå i en ny procentvis opgørelse af den effektive undervisningstid, som blev prioriteret højt af lærerne i nærværende undersøgelse. Men et større udvalg af mine induktivt udledte temaer ville med høj sandsynlighed kunne iagttages i andre casestudier. Denne forventning hviler på, at flere af temaerne har almen karakter og er velkendte i litteraturundervisningen. Dette er fx viden om voerket, forståelse af vorket og karakteristikker. Historisk viden og geografisk viden anser jeg som værende af mere specifik art. Lærerne i denne undersøgelse valgte at arbejde med et værk, der beskæftiger sig med historiske forhold under 2. verdenskrig, hvilket påvirkede de udledte temaer.

Valget af Blooms taksonomi var en styrke i kodning af danskundervisning, da analyse og fortolkning kunne adskilles. Bloom blev valgt frem for den reviderede udgave, der er udarbejdet af Lorin W. Anderson \& David R. Krathwohl (2001). Revisionen er en videreudvikling af Blooms taksonomi. Jeg holdt fast i Blooms originale udgivelse, da revisionen ikke adskiller analyse og fortolkning lige så stringent som i Blooms taksonomi. I stedet er revisionen opbygget 
efter følgende kategorier: huske, forstå, anvende, analysere, vurdere og skabe (Anderson \& Krathwohl, 2001). I denne opdeling er fortolkning ikke i sin egen kategori. Samme problematik er gældende for andre velkendte taksonomiske modeller som fx SOLO-taksonomien (Structure of Observed Learning Outcome) (Biggs \& Tang, s. 87, 2011). Det var derfor afgørende for min udvælgelse af relevante teoretiske opdelinger, at analyse og fortolkning nødvendigvis måtte befinde sig i hver sin kategori, for at jeg kunne isolere og operationalisere dem til danskfaglige begreber.

To temaer bør der rettes særlig opmærksomhed på i kritisk øjemed: elevens erfaringsverden og meddigtning. Disse to tematikker voldte besvær at placere i en taksonomisk tænkning. Elevens erfaringsverden blev placeret som laveste taksonomiske niveau under argumentet, at Blooms taksonomi er rettet mod et fagfelt. I denne tænkning tages der ikke højde for elevernes hverdagserfaringer, personlige holdninger, synsninger, oplevelser og meninger. Dette betyder ikke, at elevernes erfaringer ikke er vigtige i litteraturundervisningen, men at den er ureflekteret, når den ikke møder modspil, bliver undersøgt, sættes i kontekst og/eller bliver diskuteret. Derudover har placeringen af det danskfaglige begreb meddigtning været vanskelig. Dette tema blev placeret i indholdskategorien fortolkning under argumentet, at elevernes besvarelser både har en ret i sig selv som et produkt, men samtidig hviler på værkets organisation af idéer. Da opgaveformuleringerne i meddigtningsopgaverne fra empirien både kan lægge op til analyse og fortolkning af værket, anså jeg det som nødvendigt at placere meddigtning som enten en del af indholdskategorien analyse eller fortolkning og ikke i en selvstændig kategori. Hvis ikke meddigtningen i Blooms taksonomi hørte under én af disse kategorier, men eksempelvis i en selvstændig kategori såsom skabelse (Anderson \& Krathwohl, 2001), havde fortolkning ligget markant lavere i de procentvise opgørelser. Dette mener jeg, ville have givet et skævt billede af litteraturundervisningen, da meddigtning, ifølge Ayoe Quist Henkel (2012, s. 195), udspringer af værket og har en funktion i forhold til analyse og fortolkning. Meddigtning betragtede jeg dermed ikke udelukkende som et produkt i sig selv. Det kan diskuteres, om meddigtning hælder mest til analyse eller til fortolkning af en tekst. Det ændrer ikke på, at meddigtning kun kan rummes i Blooms definitioner under kategorien fortolkning, da det kun er hér, at produkter har berettigelse. Det var et nødvendigt onde at foretage dette valg på trods af divergerende muligheder. 


\section{Konklusion}

Undersøgelsen bidrager med viden om læremidler dér, hvor de bruges. Casestudiet har bidraget til et nuanceret indblik i læremiddelbrug og er en empirisk bekræftelse på, hvad vi allerede ved om læremidler i brug fra spørgeskema- og interviewundersøgelser: Læremidler ændrer sig, når de rammer en didaktisk praksis. I denne undersøgelse er bidraget, hvordan de ændrer sig i den faktiske brug. Der er givet indsigt i relationen mellem lærernes planlægning i form af et didaktisk design og den didaktiske praksis, hvor det didaktiske design blev anvendt. Undersøgelsen er et skridt nærmere i forhold til viden om, hvordan litteraturanalyse og -fortolkning prioriteres og praktiseres - ikke udelukkende ud fra undersøgelse af lærernes egne estimater af, hvor meget og hvordan de bruger læremidler i praksis, men den faktiske brug i danskundervisningen.

Første delundersøgelse undersøgte spørgsmålet: Hvor stor en del af danskfagets litteraturundervisning i praksis udgør henholdsvis litteraturanalyse og litteraturfortolkning i en procentvis fordeling? Undersøgelsen viser, at analysen blev prioriteret højere end fortolkning, lige som det blev påvist i den kvantitative opgørelse i Loeremidlernes danskfag (2017). I denne undersøgelse er kategorierne blot blevet kodet i en didaktisk praksis, hvor læremidler anvendes. Resultaterne af de procentviseopgørelser viser, at der i litteraturundervisningen i empirien blev praktiseret arbejde inden for andre indholdskategorier end litteraturanalyse og -fortolkning $i$ et relativt stort omfang. En betydelig del af litteraturundervisningen bestod $\mathrm{i}$ at arbejde med de simple taksonomiske niveauer, og de komplekse taksonomiske niveauer blev generelt prioriteret lavere end de simple taksonomiske niveauer.

Anden delundersøgelse undersøger spørgsmålet: Hvordan praktiseres litteraturanalyse og litteraturfortolkning i litteraturundervisningen? Resultaterne af tendenserne fra den tematiske analyse er, at litteraturanalyse og -fortolkning var de to mest isolerede indholdskategorier ud af de seks indholdskategorier. Tendensen var, at analyse og fortolkning var de to indholdskategorier som oftest: 1) blev praktiseret adskilt fra hinanden og fra de resterende indholdskategorier i hver deres vakuum, 2) blev praktiseret under individuelt arbejde, gruppearbejde og som lektier og 3) blev praktiseret i korte opsamlinger på klassen og blev sjældent sat til genstand for diskussion.

I en skolepraksis kan undersøgelsen bidrage til diskussion om, hvorvidt litteraturanalyse og -fortolkning er prioriteret og praktiseret hensigtsmæssigt. Men heri ligger der også et normativt sigte: Hvordan $b ø r$ litteraturanalyse og -fortolkning prioriteres og 
praktiseres? Forskning viser, at litteraturanalyse bliver prioriteret højt i både læremidlerne og undervisningen, og analyseskemaer samt det danskfaglige begrebsapparat praktiseres i høj grad (Bremholm, Bundsgaard, Fougt \& Skyggebjerg, 2017; Hansen, Elf, Misfeldt, Gissel og Lindhardt, 2020). Nærværende undersøgelse understøtter denne forskning ved at pege på, at litteraturanalysen både fylder i dens tilstedeværelse i klasselokalet og lektierne og oftest ikke sættes i direkte spil med fortolkningen. Der må nødvendigvis rettes en kritik af denne måde, at bedrive litteraturundervisning på. Litteraturanalysen risikerer at blive et mål i sig selv og får en funktion, der ikke nødvendigvis giver udslag $\mathrm{i}$, at eleverne bliver kritisk reflekterende, empatiske, demokratiske - og alle de andre begrundelser for litteraturundervisningens legitimitet. Litteraturanalysen kan åbne litteraturen, men den forbliver mekanisk, hvis den ikke rører ved elevens erfaringsverden og danner grundlag for fortolkning og kritisk refleksion. Hvis litteraturundervisningen skal lykkes bør litteraturen sætte præg på sin læser ved indsigt og indlevelse. Det kan litteraturanalysen dog ikke i sig selv, men den er nødvendig for, at eleven kan komme et stykke ad vejen.

\section{Fremtidige studier}

I dette casestudie havde de to deltagende lærere kun ladet sig inspirere af et didaktisk læremiddel fra den digitale fagportal Clio. Dette understøtter den eksisterende forskning i, at lærerne tilpasser læremidler efter behov og ikke ønsker at følge instrukser minutiøst fra didaktiske læremiddelsystemer, der dikterer, hvordan undervisningen skal gennemføres (Meidl, 2013; Lenski et al., 2016). Især har aspektet one size fits all i systemer mødt kritik samt risikoen for, at lærerens autonomi kompromitteres, hvis læremidler anvendes med absolut nøjagtighed (White, 2012; Harnett-Edwards, 2012). Som en naturlig følge redidaktiserer lærerne til deres specifikke målgruppe ud fra deres professionelle dømmekraft. Det er derfor nødvendigt at se flere undersøgelser, hvor der tages udgangspunkt i didaktiske læremidler i brug i et klasselokale. For at klarlægge den dynamiske læremiddelproces må undersøgelserne inkludere den didaktiske intention i læremidlet til og med, at undervisningen er afsluttet. Jeg vil fremhæve digitale fagportaler som et særligt interesseområde for fremtidige studier. Senest har en statslig tilskudsordning (Undervisningsministeriet, Finansministeriet, KL, Ministeriet for Børn, Ligestilling, Integration og Sociale Forhold \& Økonomi- og Indenrigsministeriet, 2014) været medvirkende til, at didaktiske digitale læremidler er blevet udbredt (Rambøll 2018, s. 28). En rapport 
fra Rambøll (2018) viser, at de digitale fagportaler ofte danner rammen for et undervisningsforløb og har stor indflydelse på undervisningen. I forhold til digitale didaktiske læremidler i danskfaget har feltet en specifik mangel på forskning i anvendelsen af de digitale fagportaler (eksempelvis Clio, Gyldendal, Alinea) (Tannert \& Berthelsen, 2020). Dette er problematisk, idet den kvantitative opgørelse i Loeremidlernes danskfag viser, at de digitale fagportaler i udskolingen "indtager en langt mere dominerende plads sammenlignet med indskoling og mellemtrin" (Bundsgaard, Buch \& Fougt, 2017, s. 33). I udskolingen er der tale om 50\% af brugen af læremidler (Bundsgaard, Buch \& Fougt, 2017, s. 44), og 34\% af lærerne i undersøgelsen udpeger de digitale fagportaler som de bedste læremidler (Bundsgaard, Buch \& Fougt, 2017, s. 34). Det synes dermed ikke urimeligt at formode, at de digitale fagportaler har indflydelse på danskundervisningen. Vi står dermed med et forskningslandskab, der generelt kalder på empiriske undersøgelser i faktisk læremiddelbrug og specifikt kalder på vinklen, der fokuserer på anvendelsen af de digitale fagportaler i danskundervisningen.

\section{Referencer}

Anderson, L. W. \& Krathwohl, D. R. (Red.) (2001). A Taxonomy for Learning, Teaching, and Assessing - A Revision of Bloom's Taxonomy of Educational Objectives. Longman.

Bachmann, K., Sivesind, K., Afsar, A. \& Hopmann, S. (2003). Lcerebøkenes rolle $i$ iverksettingen av Reform 97. Delrapport innenfor prosjektet Evaluering av L97. Hvordan formidles læreplanen? - en komparativ evaluering av læreplanbaserte virkemidler - deres utforming, konsistens og betydning for læreres praksis.

Biggs, J. B. \& Tang, C. (2011). Teaching for Quality Learning at University - What the Student Does. Open University Press.

Blikstad-Balas, M. (2017). Key challenges of using video when investigating social practices in education: contextualization, magnification, and representation. International Journal of Research \& Method in Education, 40(5), 511-523 DOI: $10.1080 / 1743727$ X.2016.1181162

Bloom, B. S. (Red.) (1975) [1956]. Taxonomy of Educational Objectives. The Classification of Educational Goals. Handbook 1: Cognitive Domain. McKay.

Boolsen, M. W. (2017). Kvalitative analyser - At finde årsager og sammenhœenge. Hans Reitzels Forlag.

Bremholm, J., Bundsgaard, J., Fougt, S. S. \& Skyggebjerg, A. (2017). Loeremidlernes danskfag. Aarhus Universitetsforlag.

Bremholm, J. \& Skott, C. K. (2019). Teacher planning in a learning outcome perspective: A multiple case study of mathematics and Li Danish teachers. Acta Didactica Norge, 13(1), 1-22. DOI: https://doi.org/10.5617/adno.5540

Bryman, A. (2012). Social Research Methods. Oxford University Press. 
Bueie, A. A. (2002): Loerebokvalg - en formalisert og systematisk prosess? En undersøkelse av valg av loerebøker for norskfaget $i$ den videregående skolen. Høgskolen i Vestfold. Rapport 11/2002. Lokaliseret 14. januar, 2021 på: https:// www.researchgate. net/profile/Agnete_Bueie/publication/242467871_ Laerebokvalg_en_formalisert_og_systematisk_prosess_En_undersokelse_ av_valg_av_laereboker_for_norskfaget_i_den_videregaende_skolen/ links/53fiaafoocf26b9b7ddode66/Laerebokvalg-en-formalisert-og-systematiskprosess-En-undersokelse-av-valg-av-laereboker-for-norskfaget-i-denvideregaende-skolen.pdf

Bueie, A. A. (2003). Er det sammenheng mellom bruk og valg? En undersøkelse av hvordan loereboken brukes i norskfaget $i$ den videregående skolen - sett $i$ sammenheng med hvordan loerebøker velges. Høgskolen i Vestfold. Rapport 11/ 2003.

Bundsgaard, J., Buch, B. \& Fougt, S. S. (2017). De anvendte læremidlers danskfag belyst kvantitativt. I: J. Bremholm, J. Bundsgaard, S. S. Fougt \& A. K. Skyggebjerg (Red.), Loremidlernes danskfag (s. 28-54). Aarhus Universitetsforlag.

Burkhauser, M. A., \& Lesaux, N. K. (2007). Exercising a bounded autonomy: Novice and experienced teachers' adaptions to curriculum materials in an age of accountability. Journal of Curriculum Studies, 49(3), 291-312. DOI: https://doi.org/1 0.1080/00220272.2015.1088065

Christophe, B., Bock, A., Fuchs, E., Macgilchrist, F., Otto, M. \& Sammler, S. (2018). New Directions. I: E. Fuchs \& A. Bock (Red.), The Palgrave Handbook of Textbook Studies (s. 413-421). Palgrave Macmillan.

Dale, E. L. (1999). Pcedagogik og professionalitet. Forlaget Klim.

Danskfaget (Clio) (u.å). Værkforløbet Med ilden i ryggen. Lokaliseret 13. januar, 2021, på: https://portals.clio.me/dk/dansk/7-10/forloeb/showunitplan/?unit_plan=9fo35586- bfff-7d86-b8e1-c9c4936cabbb\&is_ preview=1\&cHash=3oocd2eef5601d8f33429coo21596626

DeCesare, M. (2007). Textbook Approach to Teaching: Structural Uniformity among American High School Sociology Courses. American Sociologist, 38, 178-190. Lokaliseret d. 17 marts, 2021, på: https://www.researchgate. net/publication/226758826_A_Textbook_Approach_to_Teaching_Structural_ Uniformity_among_American_High_School_Sociology_Courses

Elf, N. F. \& Hansen, T. I. (Red.) (2017). Hvad vi ved om undersøgelsesorienteret undervisning i dansk: Og hvordan vi kan bruge denne viden til at skabe bedre kvalitet $i$ danskfagets litteraturundervisning i grundskolen. Læremiddel.dk Nationalt Videncenter for Læremidler. Lokaliseret d. 14.januar, 2021, på: http:// laeremiddel.dk/wp-content/uploads/2017/12/Forunders\%C3\%B8gelse-delrapport2-dansk.pdf

Flyvbjerg, B. (2015). Fem misforståelser om casestudiet. I: S. Brinkmann \& L. Tanggaard (Red.), Kvalitative metoder (s. 497-520). Hans Reitzels Forlag.

Furst, E. J. (1994). Blooms Taxonomy: Philosophical and Educational Issues. I: L. W. Anderson \& L. A. Sosniak (Red.), Blooms Taxonomi: A Forty-year Retrospective. The University of Chicago Press.

Gabrielsen, I. L., Blikstad-Balas, M. \& Tengberg, M. (2019). The role of literature in the classroom. How and for what purposes do teachers in lower secondary school use literary texts? L1-Educational Studies in Language and Literature, 19, 1-32. DOI: 10.17239/L1ESLL-2019.19.01.13 
Gilje, Ø., Ingulfsen, L., Dolonen, J. A., Furberg, A., Rasmussen, I., Kluge, A., Knain, E., Mørch, A., Naalsund, M. \& Skarpaas, K. G. (2016). Bruk av loeremidler og ressurser for loering på tvers av arbeidsformer (ARK\&APP). Universitetet i Oslo. Lokaliseret 14. januar, 2021, på: https://www.uv.uio.no/iped/forskning/ prosjekter/ark-app/arkapp_syntese_endelig_til_trykk.pdf

Gilje, Ø. (2015). På jakt etter ark og app i fire fag i det nye norske læremiddellandskapet. Learning Tech (1), 36-61. DOI: https://doi.org/10.7146/ lt.v1i1.107619

Gissel, S. T. \& Buch, B. B. (2020). A systematic review of research on didactic learning materials in L1. Learning Tech (7), 90-129. Lokaliseret 14. januar, 2021, på: https:// learningtech.laeremiddel.dk/wp-content/uploads/2020/10/Artikel_4_7-1.pdf

Graf, S. T., Hansen, J. J. \& Hansen, T. I. (2012). Løeremidler i didaktikken - didaktikken i loeremidler. Forlaget Klim.

Grossman, P., \& Thompson, C. (2008). Learning from curriculum materials: Scaffolds for new teachers? Teaching and Teacher Education, 24, 2014-2026. DOI: https://doi.org/10.1016/j.tate.2008.05.002

Hansen, J. J. (2010). Loeremiddellandskabet. Fra loeremiddel til undervisning. Akademisk Forlag.

Hansen, T. I. (2016). Når tekster finder sted. Det kognitive scenariebegreb som basis for en undersøgelsesorienteret tekstdidaktik. Viden om literacy, (20), 37-44.

Hansen, T. I. \& Skovmand, K. (2011). Foelles mål og midler - Loeremidler og loereplaner i teori og praksis. Klim.

Hansen, T. I., Elf, N., Misfeldt, M. M., Gissel, S. T. \& Lindhardt, B. (2020). Kvalitet i dansk og matematik: Et lodtrokningsforsøg med fokus på undersøgelsesorienteret dansk-og matematikundervisning (slutrapport). Læremiddel.dk.

Harnett-Edwards, K. (2012). How scripted programs de-professionalized the teaching of reading. I: H. Hickman \& B. J. Porfilio (Red.), The new politics of the textbook: Critical analysis in the core content areas (s. 213-230). Sense Publishers.

Heath, C., Hindmarsh, J., \& Luff, P. (2010). Video in Qualitative Research: Analysing Social Interaction in Everyday Life. Sage.

Henkel, A. Q. (2017). Konturer af intermedial litteratur og litteraturdidaktik i Fælles Mål og i danskundervisningen. Studier i loereruddannelse og -profession, 2(2), 106127. https://doi.org/10.7146/lup.v2i2.27688

Henkel, A. Q. (2012). Læserorienterede arbejdsformer. I: M. Jørgensen (Red.), Videre i teksten - Litteraturpcedagogiske positioner og muligheder (s. 189-200). Hans Reitzels Forlag.

Heyerdahl-Larsen, C. (2000). Loereboken - Tvangstrøye eller helsetrøye? En teoretish og empirisk fremstilling av loerebokens rolle i undervisningen [Hovedopgave i pedagogikk, Oslo Universitet].

Hodgson, J., Rønning, W., Skogvold, A. S. \& Tomlinson, P. (2010). På vei fra loereplan til klasserom - Om loereres fortolkning, planlegging og syn på LKo6. Nordland Research Institute. Lokaliseret 14. januar, 2021, på: https://www.udir. no/globalassets/filer/tall-og-forskning/rapporter/2010/evakl/5/smul_andre.pdf

Horsley, M., \& Walker, R. (2005). Textbook Pedagogy: A Sociocultural Analysis. I: M. Horsley, S. V. Knudsen, \& S. Selander (Red.), Has Past Passed? Textbooks and Educational Media for the 21st Century. The 7th IARTEM Volume (s. 47-69). HLS. 
Juuhl, G. K., Hontvedt, M., \& Skjelbred, D. (2010). Loeremiddelforsking etter LKo6: eit kunnskapsoversyn. Høgskolen i Vestfold. Lokaliseret 14. januar, 2021, på: https://www.udir.no/tall-og-forskning/finn-forskning/rapporter/ Laremiddelforsking-etter-Kunnskapsloftet---rapport-2010/

Jørgensen, M. (2019). Toet på litteratur - Fagdidaktik og metode. Hans Reitzels Forlag.

Kaspersen, P. (2012). Litteraturdidaktiske positioner. I: M. Jørgensen (Red.), Videre i teksten - Litteraturpcedagogiske positioner og muligheder (s. 61-74). Hans Reitzels Forlag.

Klette, K. (2009). Challenges in Strategies for Complexity Reduction in Video Studies. Experiences from the PISA+ Study: A Video Study of Teaching and Learning in Norway. I: T. Janík \& T. Seidel (Red.), The Power of Video Studies in Investigating Teaching and Learning in the Classroom. Waxmann Publishing Co.

Klette, K., Blikstad-Balas, M. \& Roe, A. (2017). Linking instruction and student achievement: research design for a new generation of classroom studies. Acta didactica Norden, 11(3). doi:10.5617/adno.4729.

Knudsen, S. V. (Red.) (2011). Internasjonal forskning på loeremidler - en kunnskapsstatus. Høgskolen i Vestfold. Lokaliseret 14. januar, 2021, på: https:// www.udir.no/tall-og-forskning/finn-forskning/rapporter/Kunnskapsstatus--forskning-pa-laremidler-/

Krogh, E. (2003). Etfag i moderniteten. Danskfagets didaktiske diskurser [Ph.d.afhandling, Syddansk Universitet].

Köksal, D., \& Ulum, Ö. G. (2018). Language assessment through Bloom's Taxonomy. Journal of Language \& Linguistics Studies, 14(2), 76-88. http://search.ebscohost. com.ez.statsbiblioteket.dk:2048/login.aspx?direct=true\&db=ehh\&AN=13132419 $5 \&$ site $=$ ehost-live

Lenski, S., Larson, M., McElhone, D., Davis, D. S., Lauritzen, C., Villagómez, A., Yeigh, M., Landon-Hays, M., LeJeune, M. \& Scales, W. D. (2016). What teachers want: A state-wide survey of reading and English language arts teachers' instructional materials, preferences, and practices. Literacy Research and Instruction, 55(3), 237-261. https://doi.org/10.108o/19388071.2016.1156202

Lynggaard, K. (2015). Dokumentanalyse. I: S. Brinkmann \& L. Tanggaard (Red.), Kvalitative metoder (s. 153-167). Hans Reitzels Forlag.

Meidl, T. D. (2013). Opting out: Examining teacher's beliefs when faced with core reading programs. Current Issues in Education, 16(3), 1-11.

Mercer, N. (2010). The analysis of classroom talk: Methods and methodologies. British Journal of Educational Psychology, 80, 1-14. https://doi. org/10.1348/000709909X479853

Mullis, I. V., Martin, M. O., Foy, P., \& Arora, A. (2012). TIMSS 2011 international results in mathematics. Chestnut Hill, MA: TIMSS \& PIRLS International Study Center. Lokaliseret 14. marts, 2021, på: https://timss.bc.edu/timss2011/downloads/ T11_IR_Mathematics_FullBook.pdf

Møller, H. H., Poulsen, H. \& Steffensen, B. (2010). Litteraturundervisning-mellem analyse og oplevelse. Samfundslitteratur.

Nielsen, F. V. (2006). Didaktikkens indholdsbegreb og kriterier for valg af undervisningsindhold. I: B. G. Hansen \& A. Tams (Red.), Almen didaktik Relationer mellem undervisning og loering (s. 249-271). Billesø \& Baltzer. 
Norup, M. S. (2019). Læremidler i brug i danskfagets litteraturundervisning - en empirisk undersøgelse af litteraturanalyse og litteraturfortolkning [Kandidatspeciale, Danmarks institut for Pædagogik og Uddannelse].

Pahuss, M. (2015). Hermeneutik. I: F. Collin \& S. Køppe (Red.), Humanistisk videnskabsteori (3. udg., s. 223-263). Lindhardt og Ringhof Forlag.

Petersen, M. (1999). Med ilden i ryggen. HøST \& SØN.

Rambøll (2018). Indsatsen for it ifolkeskolen - evaluering. Rapport til Undervisningsministeriet - Styrelsen for it og læring. Lokaliseret 13. januar, 2021, på: https://www.uvm.dk/publikationer/2018/180619-evaluering-af-it-ifolkeskolen

Ramian, K. (2012). Casestudiet i praksis. Hans Reitzels Forlag.

Rødnes, K. A. (2014). Skjønnlitteratur i klasserommet: Skandinavisk forskning og didaktiske implikasjoner. Acta Didactica Norge, 8(1), 1-17. Lokaliseret 14. januar, 2021, på: https://www.journals.uio.no/index.php/adno/article/view/1097/976

Schmidt, W. H., McKnight, C. C., Houang, R. T., Wang, H., Wiley, D. E., Cogan, L. S. \& Wolfe, R. G. (2001). Why schools matter. Sansome, CA, USA: Jossey-Bass.

Schön, D. (2006). Den reflekterende praktiker - Hvordan professionelle toenker, når de arbejder. Forlaget Klim.

Sigurgeirsson, I. (1992). The role, use and impact of curriculum materials in intermediate level Icelandic classrooms [Doctoral dissertation, University of Sussex, Brighton].

Sikorová, Z. (2011). The role of textbooks in lower secondary schools in the Czech Republic. IARTEM e-Journal, 4(2), 1-22. Lokaliseret 12. marts, 2021, på: https:// doi.org/10.21344/iartem.v4i2.774

Skjelbred, D. (2003). Valg, vurdering og kvalitetsutvikling av loerebøker og andre loeremidler. Slutrapport 12/2003. Høgskolen i Vestfold.

Skjelbred, D., Solstad, T. \& Aamotsbakken, B. (2004). Kartlegging av loeremidler og loeremiddelpraksis. Høgskolen i Vestfold.

Snell, J. (2011). Interrogating Video Data: Systematic Quantitative Analysis versus Micro-Ethnographic Analysis. International Journal of Social Research Methodology, 14(3), 253-258. DOI: 10.1080/13645579.2011.563624

Stara, J. \& Krčmářová, T. (2015). How teachers reflect on textbook materials and how they utilize them. IARTEM e-Journal, 6(3), 67-87. Lokaliseret 14. januar, 2021, på: https://www.researchgate.net/publication/281632650_How_teachers_ reflect_on_textbook_materials_and_how_they_utilise_them

Szulevicz, T. (2015). Deltagerobservation. I: S. Brinkmann \& L. Tanggaard (Red.), Kvalitative metoder (s. 81-96). Hans Reitzels Forlag.

Szulevicz, T. (2015). Deltagerobservation. I: S. Brinkmann \& L. Tanggaard (Red.), Kvalitative metoder (s. 81-96). Hans Reitzels Forlag.

Tannert, M. \& Berthelsen, U. D. (2020). Digitale læremidler i danskfaget. Poedagogisk indblik, 4. Lokaliseret 14. januar, 2021, på: https://dpu.au.dk/ fileadmin/edu/Paedagogisk_Indblik/Digitale_laeremidler/Forskningsoversigt_ Digitale_laeremidler_i_danskfaget.pdf

Tarman, B. \& Kuran, B. (2015). Examination of the Cognitive Level of Questions in Social Studies Textbooks and the Views of Teachers Based on Bloom Taxonomy. Educational Sciences: Theory \& Practice, 15(1), 213-222. https://doiorg. ez.statsbiblioteket.dk:12048/10.12738/estp.2015.1.2625 
Tjora, A. (2012). Kvalitative forskningsmetoder i praksis. Gyldendal Norsk Forlag.

Undervisningsministeriet, Finansministeriet, KL, Ministeriet for Børn, Ligestilling, Integration og Sociale Forhold \& Økonomi- og Indenrigsministeriet (2014): Aftale om konkretisering af det foelles brugerportalinitiativ for folkeskolen. Lokaliseret 13. januar, 2021, på: https:/www.kl.dk/media/11596/aftale-omkonkretisering-af-det-faelles-brugerportalsinitiativ.pdf

Ventegodt, O. (2017). Wilhelm Gustloff. I: Den Store Danske. Gyldendal. Lokaliseret d. 18.8.2021: https://denstoredanske.lex.dk/Wilhelm_Gustloff

Walsh, R., Bowes, J. \& Sweller, N. (2017). Why would you say goodnight to the moon? response of young intellectually gifted children to lower and higher order questions during storybook reading. Journal for the Education of the Gifted, 40(3), 220-246. http://dx.doi.org.ez.statsbiblioteket.dk:2048/10.1177/0162353217717032

Warren, L. L. (2000). Teacher Planning - A Literature Review. Educational Research Quarterly, 24(2), s.37.

Watt, M. (2015). Research on textbook use in the United States of America. IARTEM e-Journal, 7(2), 48-72. Lokaliseret 13. marts, 2021, på: DOI: 10.1007/s12108-0079007-9

Weinberg, A. \& Wiesner, E. (2011). Understanding Mathematics Textbooks Through Reader-Oriented Theory. Educational Studies in Mathematics, 76(1), 49-63. Lokaliseret 4. April, 2021, på: DOI:10.1007/S10649-010-9264-3

White, J. W. (2012). From textbooks to "managed instructional systems": Corporate control of the English Language Arts. I: H. Hickman \& B. J. Porfilio (Red.), The new politics of the textbook: Critical analysis in the core content areas (s. 193212). Sense Publishers. Lokaliseret 23. marts, 2021, på: https://www. researchgate.net/publication/267026590_From_textbooks_to_\%27managed_ instructional_systems\%27_Corporate_control_of_the_English_Language_Arts Yin, R. K. (2018). Case Study Research: Design and Methods. SAGE Publications. 